\title{
Severe left ventricular dysfunction in an infant
}

\author{
Odete Mingas 다, ${ }^{1}$ Natália Noronha 다, ${ }^{2}$ Miguel Abecasis 지, ${ }^{3}$ Ana Teixeira ${ }^{4}$
}

\begin{abstract}
${ }^{1}$ Paediatric Cardiology, Hospital de Santa Cruz, Carnaxide, Portugal

${ }^{2}$ Paediatric Cardiology, Centro Hospitalar de Lisboa Ocidental EPE Hospital de Santa Cruz, Carnaxide, Portugal ${ }^{3}$ Cardiac Surgery, Centro Hospitalar de Lisboa Ocidental EPE Hospital de Santa Cruz, Carnaxide, Portugal ${ }^{4}$ Pediatric Cardiology, Centro Hospitalar de Lisboa Ocidental EPE, Carnaxide, Portugal
\end{abstract}

Correspondence to Dr Odete Mingas: tch.uca@hotmail.com

Accepted 16 May 2021
A) Check for updates

(c) BMJ Publishing Group Limited 2021. No commercial re-use. See rights and permissions. Published by BMJ.

\begin{tabular}{l}
\hline To cite: Mingas O, \\
Noronha N, Abecasis M, \\
et al. BMJ Case Rep \\
2021;14:e241092. \\
doi:10.1136/bcr-2020- \\
241092 \\
\hline
\end{tabular}

\section{DESCRIPTION}

A 5-month-old infant with poor weight gain was taken to the emergency department due to respiratory distress and feeding intolerance. On examination, she was tachypnoeic and was wheezing and was diagnosed with bronchiolitis. On heart auscultation, however, there was a grade II/VI holosystolic murmur on the left lower sternal border with irradiation to the axilla. Her liver was palpable $4 \mathrm{~cm}$ below the right costal margin and she had poor weight gain. Chest X-ray showed cardiomegaly (cardiothoracic index of 70\%), which prompted referral to paediatric cardiology. ECG showed repolarisation anomalies in the left precordial leads, suggesting dilation of the left ventricle (LV); however, there were no signs of ischaemia. Echocardiogram showed LV dilation-diastolic diameter of $46 \mathrm{~mm}(Z$-score +12$)$, ejection fraction of $25 \%$ and moderate mitral regurgitation due to poor leaflet coaptation. The left coronary artery originated from the main pulmonary artery and there was retrograde flow in the left anterior descending artery (figure 1).

She was referred for cardiac surgery exclusively based on these investigations. ${ }^{12}$

The surgical procedure was carried out through median sternotomy, under circulatory support, and myocardial protection was provided with hypothermia and administration of a cardioplegic solution and aortic cross-clamping. On inspection, the right coronary artery was markedly dilated (figure 2). The pulmonary trunk was transected above the level of the left coronary artery. The left coronary artery button was dissected and reimplanted in the aorta, creating a double flap. The pulmonary artery was anastomosed end-to-end with direct suture. ${ }^{34}$ Blood pressure was controlled

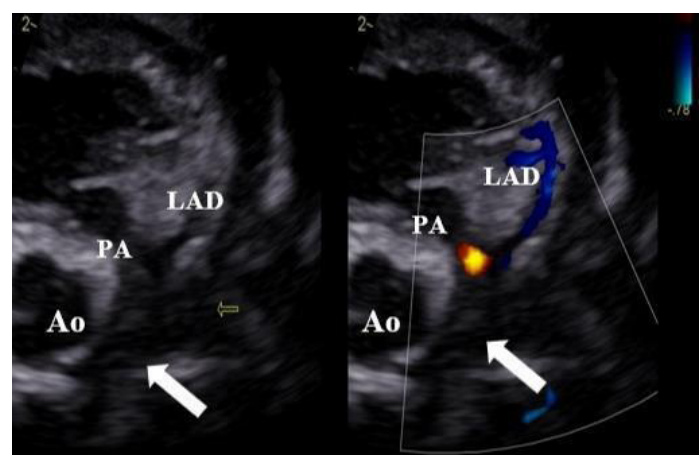

Figure 1 Transthoracic echocardiogram: parasternal short axis showing the left coronary artery originating from the main pulmonary artery (arrows); colour Doppler showing retrograde flow in the left anterior descending artery entering the PA in diastole. Ao, aorta; $L A D$, left anterior descending artery; PA, pulmonary artery.

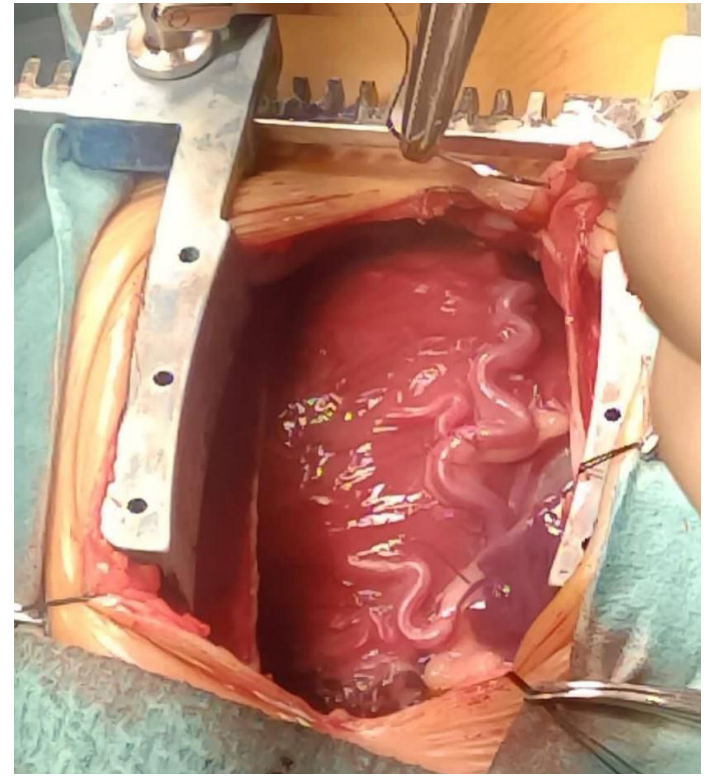

Figure 2 Intraoperative image: right coronary artery enlargement due to the development of extensive collateral coronary circulation.

intraoperatively and was normal. The chest was closed and the infant was transferred to the intensive care unit on mechanical ventilation and inotropic support. Postoperative echocardiogram showed LV dilation with severe dysfunction, but with improved segmental contractility, anterograde flow in the anterior descending artery, mild mitral regurgitation and right ventricle with good function. Despite being haemodynamically stable over the following hours, she went into cardiorespiratory arrest during aspiration of respiratory secretions and could not be resuscitated.

\section{Patient's perspective}

We realised that our child's respiratory symptoms were related to the cardiac dysfunction. We understand the importance of early referral for Paediatric Cardiology of any child with poor weight gain and cardiomegaly, with or without murmur. We are grateful to the medical team for having made an accurate diagnosis before serious damages ensued.

Contributors AT has received the child and collected all data supporting the diagnosis and suggested treatment. MA performed the surgery. OM and NN wrote the case and gathered literature.

Funding The authors have not declared a specific grant for this research from any funding agency in the public, commercial or not-for-profit sectors.

Competing interests None declared. 


\section{Learning points}

- Anomalous left coronary artery from the pulmonary artery (ALCAPA) is a very rare congenital anomaly that accounts for $0.25 \%-0.5 \%$ of all heart diseases, with a mortality rate of $90 \%$ during childhood when untreated, and the diagnosis of this entity requires a high index of suspicion.

- Failure to thrive in an infant should prompt thorough aetiological investigation as it may be a sign of a severe underlying condition.

- It is mandatory to exclude ALCAPA as a cause of dilation and left ventricle dysfunction in infants since at this stage it is amenable to surgical correction with good prognosis.
Patient consent for publication Parental/guardian consent obtained.

Provenance and peer review Not commissioned; externally peer reviewed.

\section{ORCID iDs}

Odete Mingas http://orcid.org/0000-0002-7977-4900

Natália Noronha http://orcid.org/0000-0001-9442-1444

Miguel Abecasis http://orcid.org/0000-0003-0323-741X

\section{REFERENCES}

1 Araújo AR, Mendes IC, Magro P, et al. Disfunção ventricular Grave MAS reversível no lactente. Rev Port Cardiol 2015;34:365-6.

2 Teixeira AM, Pereira J, Anjos R. Anomalous origin of the left coronary artery from the pulmonary trunk. Cardiol Young 2004:14:439-40.

3 JC Queiroz de França y col. Longa sobrevivência em paciente com síndrome de ALCAPA. Insuf Card, 2018: 13. 40-4. http://www.insuficienciacardiaca.org

4 Amaral ME, Epifânio P, Noronha N, et al. Causa RARA de disfunção ventricular esquerda em idade pediátrica. Rev Port Cardiol 2019:38:159.e1-5.

Copyright 2021 BMJ Publishing Group. All rights reserved. For permission to reuse any of this content visit

https://www.bmj.com/company/products-services/rights-and-licensing/permissions/

BMJ Case Report Fellows may re-use this article for personal use and teaching without any further permission.

Become a Fellow of BMJ Case Reports today and you can:

- Submit as many cases as you like

- Enjoy fast sympathetic peer review and rapid publication of accepted articles

- Access all the published articles

Re-use any of the published material for personal use and teaching without further permission

Customer Service

If you have any further queries about your subscription, please contact our customer services team on +44 (0) 2071111105 or via email at support@bmj.com.

Visit casereports.bmj.com for more articles like this and to become a Fellow 